\title{
ENGLISH TEACHERS' PERCEPTION AND STRATEGIES TOWARDS THE USE OF CODE-SWITCHING IN TEACHING EFL YOUNG LEARNERS
}

\author{
Putu Andre Sastra Wiguna ${ }^{1}$, Kadek Yunita Adriyanti ${ }^{2}$ \\ ${ }^{1,2}$ Universitas Pendidikan Ganesha \\ Email: ptandresastraw@gmail.com
}

\begin{abstract}
The study was aimed to investigate the English teachers' perception of the effectiveness of using code-switching to the EFL young learner at SD Lab Undiksha Singaraja, Bali and to find out the strategy used by the teachers in using code-switching to teach the EFL young learners. The study used mixed method design with 5 English teachers of SD Lab Undiksha as the participant. A questionnaire with a total of 18 items was distributed and an interview was conducted to collect the data related to the teachers' perception, which covered the teachers' perception related to the teachers' persona, subject access, classroom management, and interpersonal relations. Then, to answer the second research question related to the strategy of code-switching used by the teachers, an interview was conducted. The result showed that there were 50\% teachers had positive perception in relation to teachers' persona, $70 \%$ teachers had positive perception in relation to subject access, $84 \%$ teachers had positive perception in relation to classroom management, and $80 \%$ teachers had positive perception in relation to interpersonal relations. Relating to the strategy, the results revealed that the teachers usually did code-switching whenever they introduced or say English vocabulary that were considered new or difficult for the students. It was done by either inserting the English or Bahasa Indonesia words in between their utterance. This indicated that the perception towards code-switching in teaching English was perceived positively and was implemented in order to ease the students in understanding the target language.
\end{abstract}

Keywords: code-switching, perception, young learners

(1) (1)

This work is licensed under Creative Commons Attribution License 4.0 CC-BY International license

\section{INTRODUCTION}

\subsection{Introduction}

Kachru (1992) introduced the concept of the geographic and historical spread of English into three circles (Ratminingsih, 2017). These three circles are inner circle, outer circle, and expanding circle. Inner circle refers to the country that uses English as their native language or the traditional bases, like USA, UK, Canada, and Australia. Outer circles refer to the country that uses English as the second language and English also plays the important role in the government and educational affairs. The countries that belong to this circle are Malaysia, India, and 
Singapore. Meanwhile, expanding circle refers to English which is used as a foreign language for several countries such as China, Japan, Korea, and Indonesia. Indonesia belongs to this group (Ratminingsih, 2017). Although English does not use as a medium of communication in official domains like government, business, and educational affairs in Indonesia, it is widely recognized that English is very important as an international language. Besides, English is still seen as a priority and it is important to be taught for Indonesian students (Lauder, 2008).

In Indonesia, English has been taught as a foreign language over seventy years and it is being made as a compulsory subject soon after the Indonesian Independence day in 1945 (Marlina, 2013). EFL is regarded as English as a Foreign Language. In the context of language learning, EFL is mainly used by non-native English learners, such as Indonesian learners of English in Indonesia (Bhatti \& Pathan, 2016). Nowadays, English is still being taught for elementary school students although there is an issue of the banning of English on the 2013 curriculum (Istiqomah, 2016). Therefore, many elementary schools in Indonesia teach English as the local content subject. However, it still considered as an important subject to be taught, especially for elementary school students.

Elementary school students are categorized as young learners. As young learners, the way they accept the English learning is different from the adult learners. According to Purwaningsih as cited in Ummah (2017), young learner are the students from 9-10 years old and state English as foreign language. Since English is a foreign language for them which doesn't used as a medium of communication and the fact that they are still children, the teacher should think about how to teach English for young learners. It becomes the most challenging task for the teacher to make the children learn English with fun atmosphere (Lauder, 2008). There are many strategies that can be used in teaching English for young learners, such as using games, songs, storytelling, and many more (Ummah, 2017). Although these strategies are very appropriate for young learners, there is one thing that can cause difficulty for them to teach English, it is the use of English as the language of instruction in learning activity. Therefore, there is one technique that can be used by the teacher to deal with this problem. It is code-switching.

Even though publication related to code-switching as an alternation of language was firstly done by Grosjean (1982), the term itself was firstly introduced by Haugen (1956). It was proposed as something that often done by bilinguals who often switch the use of certain words or phrases from different languages in their speech. (Nurhamidah, Fauziati, \& Supriyadi, 2018). Gustavsson and Karakitsos (2019) suggest a definition for the term as linguistic occurrence that can be described as an alternative in the broadest sense within the same context between two or more languages codes. Code-switching is a common term for bilinguals. Bilinguals tend to switch their languages during a conversation, often within single utterances (Cantone, 2007).

In the context of English Language Teaching for foreign learners, code-switching is common for the teachers and the students. Stylianou (2015) stated the issue of code-switching in an EFL classroom is not only unavoidable but it is also necessary. It is important to understand when the code is switched, and how, teachers should find a place for their mother tongue so that students can achieve the best results without forgetting the target language (Y1ldirım, 2015). Khaerunnisa (2016) reported that in the context of EFL learning, the use of mother tongue in the teaching process is something inseparable as the students need context from the language that 
they are familiar with. In the code-switching process, the teacher uses English and the understandable language of students including their mother tongue.

The use of code-switching as a communication strategy by the teacher in an EFL classroom has become an interesting phenomenon to be studied, therefore there were many studies conducted about this phenomenon. In Altun's (2019) study which investigated teachers' perceptions towards the interaction of code-switching, the teachers were not aware of the fact that they did code-switching during the class which was much and long. They said that it was due to the ease they felt when speaking with mother language. In contrast, the study conducted by Chen (2016) investigated teacher code-switching in EFL classrooms at the tertiary level in China. As a result, some teachers reported that they have the feeling of fear of the use of L1 would hinder students' L2 acquisition process. In the same study, some teachers also revealed the feeling of embarrassment because they were expected to speak fluent English, which might made students doubt their proficiency when code-switching were to be done. Besides that, they were also worried that students could be more attached to their L1 rather than learning to master the L2 (Chen, 2016). Chen's study similar to the study from five years before, by (Yao, 2011) in which he examined teachers' attitudes toward code-switching in EFL classes. He found that numbers of teachers often avoid using code-switching as they were worried that it would hinder students from speaking in the target language.

Meanwhile, Stylianou (2015) and Khaerunnisa (2016) studies show that teachers perceived code-switching as a strategy in teaching English. Stylianou (2015) stated in her study that when the teachers do code-switching from one language to the other, it is their strategy to help the students to feel at ease in using the target language without having to mean that they should use L1 frequently and forget about L2. Similarly, a study by Khaerunnisa (2016) found that code-switching was used as a strategy to provide clearer explanation and instruction for the students so that they could have better understanding of the topics being learned. Besides these two researchers, Ansar (2017) also stated that code-switching can be a strategy for teachers, it can be seen in the result of his study in which code-switching becomes strategies learning to develop the students' skill in the English language when teaching foreign language in the classroom.

An interesting finding from Bilgin (2016) was found when he conducted a study in a private school in İzmit, Kocaeli, Turkey, to five teachers who teach 5th to 10th grade students. The result shows the teachers were haunted by the thought that they don't have adequate knowledge of language like the native speaker so that they decide to do code-switching occasionally. Besides, the teachers believe that it is impossible to create an "L1 Free" classroom in English class except with highly motivated classes. The other study also supports Bilgin's finding of the impossible of "L1 Free", it is the study from Danuatmadja (2016) which conducted in Kindergarten in Central Java, Indonesia. So, he found the teachers realize that the students have a different level of English proficiency and they also realize that not all students feel confident in practicing English speaking so that it is important for them to use code-switching to avoid negative atmosphere. The other study also stated that most of the Pakistani young learners agree to use their mother tongue to convey their message effectively (Chughtai, Khan, \& Khan, 2016). Song and Lee (2019) examined the use of teacher code-switching for very young EFL learners in which the participants were 72 children, from four classes, in a private preschool in 
Daejeon, Republic of Korea. An interesting finding from their study is that the teacher can help young learners to get some new vocabularies in the target language by using code-switching in a classroom.

Bhatti, Shamsudin, \& Said (2018), in their study, found that teachers use code-switching because it has function before and during the lesson including greetings, chatting, building solidarity, and intimate relationship, accelerating the warm-up session, maintaining discipline, and getting the attention of the students. It is the same as Suganda, Loeneto, \& Zuraida's (2018) study in which the teachers reported code-switching has the function of developing or maintaining solidarity or friendship between teachers with their students, showing an understanding of students' reaction or problems, and to joke or to warn the students. Meanwhile, the study conducted in Kupang city High School, Indonesia by Amalo (2018) shows 100\% of respondents (the teachers) agreed that the use of code-switching will make the English learning process more efficient because it is one of time-saving technique. The other study from Luo (2019) who examined students' perceptions of teacher code-switching in EFL Speaking Classrooms shows that by using code-switching, the teacher can facilitate students as bilingual dictionaries as opposed to monolingual teachers.

Based on those studies, it can be seen that most of them were still discussing mainly on the effects code-switching had on the students. Given the scarcity of literature on teachers' perceptions that focus on their situation when using code-switching to students and the scarcity of using code-switching in EFL young learners in Indonesia, therefore the findings of this study will shed light on this research gap. Based on the phenomena, this present study had two aims. The first one was to investigate the English teachers' perception on the use of code-switching to teach the EFL young learners at SD Lab Undiksha Singaraja, Bali. The second one was to find out the strategy used in using code-switching to teach the EFL young learner. Using codeswitching to teach English for young learners is not only the way to make the English learning easier for the children. However, there must be some strategies need to be considered by the teachers, so that it will create meaningful learning and they can learn the target language even though with the help of their mother tongue, Balinese, and the nation language, Bahasa Indonesia.

\subsection{Research questions}

This study aimed at answering two main research questions, which are presented as follows.

1.2.1 What is the English teachers' perception on the use of code-switching to teach the EFL young learners at SD Lab Undiksha Singaraja, Bali?

1.2.2 What is the strategy used in using code-switching to teach the EFL young learner?

\subsection{Significance of the study}

The results of this study are expected to give positive contributions towards future researchers. It is because the study arose in response to the scarcity of literature on teachers' perceptions that focus on their situation when using code-switching to students and the scarcity of using code-switching in teaching EFL young learners in Indonesia. Thus, the results of this study can serve as a literature and reference for other researchers. 


\section{METHOD}

\subsection{Research Design}

This study used mix method design, namely sequential mixed method. Creswell and Plano Clark (2007) stated that mixed method is an approach that combining both qualitative and quantitative methods (Creswell \& Clark, 2007). Meanwhile, sequential mixed method is the procedures in which the researcher elaborates the findings of quantitative method with qualitative method or vice versa. The use of mixed method in this study was quantitative as a complementary method and qualitative dominantly that makes the data stronger. The data related to the teachers' perception were in forms of quantitative data. However, the data description and presentation was done qualitatively. The data related to the strategies were mainly explained qualitatively.

\subsection{Samples/Participants}

The participants in this study were five English teachers in SD Lab Undiksha Singaraja who teach English from the first grade to the sixth-grade students in this school. As the information, SD Lab Undiksha is one of the elementary schools in Singaraja, Bali that teach English from the first grade of students.

\subsection{Instruments}

To answer the research questions, the data were collected using questionnaire to collect quantitative data and followed by conducting an interview to collect qualitative data used to explain and support the quantitative data. Therefore, the instruments used were questionnaire and interview guide. The data of the perception of the English teachers' were gathered through questionnaire and interview guide. Both of these instruments were developed with regards to the teachers' persona, subject access, classroom management, and interpersonal relations. Meanwhile, the data of the strategy used by the English teacher in using code-switching was collected using interview guide. The data were transcribed, translated, and interpreted. For the data related to the code-switching strategy used by the teachers, an interview guide was also used. Both of the interviews were semi-structured, meaning that there were already list of questions and procedures followed in the conduct. However, the researcher had the ability to probe the English teachers for additional details.

To achieve the validity, the questionnaire was examined by two experts in term of inappropriateness of the items. The result of content validity of the questionnaire showed that the first judge stated there was 5 invalid items while the second judge stated that was no invalid item in the questionnaire. It means that 5 items from 25 items dropped. From the result of content validity, it was found that the result showed 0.89 which indicates a high validity. After conducing validity test by using expert judgment, the questionnaire was tried out and tested to find out the reliability by using SPSS program. The result of reliability test showed that the value of Cronbach alpha is .769. A high reliability instrument is suggested to have at least .8 Cronbach Alpha. From the table of Item-Total Statistics, several items are needed to be dropped in order to achieve .8 by dropping 2 items. After dropping 2 items, the value of Cronbach alpha is .803 which is higher than .8 . This indicated that the questionnaire has a high reliability. Therefore, there are 18 items in the questionnaire that distributed to the participants. 


\subsection{Data analysis}

The results of the questionnaire used to answer the first question were further analyzed in order to interpret the data and relate them to the study. The results were converted into percentage by dividing the total response of all the teachers with the numbers of the respondents and multiplying it with $100 \%$. The formula for the analysis is presented as follows.

$$
\begin{aligned}
& \mathrm{S}=\frac{R}{N} \times 100 \% \\
& \text { Note: } \\
& \mathrm{S}=\text { Percentage } \\
& \mathrm{R}=\text { Total response } \\
& \mathrm{N}=\text { Total respondents }
\end{aligned}
$$

Regarding the data obtained from the interview used to answer the second research question about the strategy used by the teachers, the data were analyzed by adapting the data analysis process suggested by Miles and Huberman (1994). The data analysis process consists of three stages, which are data reduction, data display, and conclusion drawing or interpretation. In the data reduction stage, the collected data were reduced and selected so that only the important and necessary data were used for the study. Then, the data were presented in the data display stage, which were then concluded in the last phase.

\section{FINDINGS AND DISCUSSION}

\subsection{Findings}

Some interesting results were found from the data collection. The findings of English teachers' perception presented from each aspect mentioned previously. Some related data regarding to the strategy used by the English teachers in code-switching were presented afterwards. Instead of mentioning the teachers' names, the researcher used codes, which were T1 (Teacher 1) until T5 (Teacher 5) in order to keep the participants' personal data.

\section{English Teachers' Perception towards the Use of Code-Switching}

As stated on the method, there are four aspects which were the focus of this study related to the teachers' perception towards the use of code-switching; namely teachers' persona (items 1 to 4), subject access (items 5 to 8), classroom management (items 9 to 13), and interpersonal

\begin{tabular}{|c|c|c|c|c|c|}
\hline Aspect & \multicolumn{4}{|c|}{ Teachers' Persona $(\%)$} & $\begin{array}{l}\text { Average } \\
(\%)\end{array}$ \\
\hline \multicolumn{6}{|l|}{ Percentage } \\
\hline Response & $\mathrm{S} 1$ & $\mathrm{~S} 2$ & S3 & $\mathrm{S} 4$ & \\
\hline Strongly agree & 20 & 0 & 0 & 0 & 5 \\
\hline
\end{tabular}
relations (items 14 to 18). The data were presented in frequency tables, in the forms of percentage for each aspect. The teachers' perception towards code-switching in relation to teachers' persona is presented on Table 1.

Table 1. Teachers' Perception towards Code-switching in Relation to Teachers' Persona 


\begin{tabular}{lccccc}
\hline Agree & 80 & 20 & 20 & 60 & 45 \\
\hline Neutral & 0 & 20 & 40 & 40 & 25 \\
\hline Disagree & 0 & 60 & 40 & 0 & 25 \\
\hline Strongly Disagree & 0 & 0 & 0 & 0 & 0 \\
\hline
\end{tabular}

Note: $\mathrm{S} 1=$ Statement 1 , and so on

Looking at Table 1, it can be seen that 5\% teachers responded with strongly agree, $45 \%$ teachers responded agree, 25\% teachers responded neutral, 25\% teachers responded disagree, and no one or $0 \%$ responded strongly disagree. This means that $50 \%$ teachers had positive perception, $25 \%$ teachers had neutral perception, and 25\% teachers had negative perception. It shows that there was a relatively fair number of teachers who still considered they had good persona when switching codes from English to Bahasa Indonesia or vice versa when teaching.

For the second aspect relating to the use of code-switching and its relation to subject access, Table 2 presents the results of the data analysis.

\section{Table 2. Teachers' Perception towards Code-Switching in Relation to Subject Access}

\begin{tabular}{|c|c|c|c|c|c|}
\hline \multirow{2}{*}{$\frac{\text { Aspect }}{\text { Percentage }}$} & \multicolumn{4}{|c|}{ Subject Access (\%) } & \multirow[t]{2}{*}{$\begin{array}{l}\text { Average } \\
(\%)\end{array}$} \\
\hline & & & & & \\
\hline Response & S5 & S6 & S7 & S8 & \\
\hline Strongly agree & 0 & 0 & 0 & 0 & 0 \\
\hline Agree & 80 & 60 & 60 & 80 & 70 \\
\hline Neutral & 20 & 40 & 40 & 20 & 30 \\
\hline Disagree & 0 & 0 & 0 & 0 & 0 \\
\hline Strongly Disagree & 0 & 0 & 0 & 0 & 0 \\
\hline
\end{tabular}

Table 2 shows the relation of code-switching to teachers' perception of subject access, whether they found it to be helpful in assisting students to understand the learning materials better. It was found that $0 \%$ or no one responded strongly agree, $70 \%$ teachers responded agree, $30 \%$ teachers responded neutral, and $0 \%$ or no one responded both disagree and strongly agree. This means that $70 \%$ teachers had positive perception, $30 \%$ teachers had neutral perception, and $0 \%$ teachers had negative perception. It shows that the teachers thought that code-switching could suppport subject access.

Table 3 showcases the results of the teachers' perception in using code-switching in relation to classroom management.

Table 3. Teachers' Perception towards Code-Switching in Relation to Classroom Management

\begin{tabular}{lcclccc} 
Aspect & \multicolumn{7}{c}{ Classroom Management (\%) } & \\
\cline { 1 - 6 } $\begin{array}{l}\text { Percentage } \\
\text { Response }\end{array}$ & S9 & S10 & S11 & S12 & S13 & Average (\%) \\
\hline Strongly agree & 0 & 0 & 20 & 0 & 0 & 4 \\
\hline Agree & 100 & 60 & 80 & 100 & 60 & 80
\end{tabular}




\begin{tabular}{llllllc} 
Neutral & 0 & 40 & 0 & 0 & 40 & 16 \\
\hline Disagree & 0 & 0 & 0 & 0 & 0 & 0 \\
\hline Strongly Disagree & 0 & 0 & 0 & 0 & 0 & 0
\end{tabular}

The third aspect aimed at investigating teachers' perception on how code-switching could assist them to discipline the students, to gain students' attention, to deliver task instruction and so on. Through Table 3, it can be seen that $4 \%$ teacher responded strongly agree, $80 \%$ teachers responded agree, $16 \%$ teachers responded neutral, and $0 \%$ or no one responded with disagree and strongly agree. This means that $84 \%$ teachers had positive perception, $16 \%$ teachers had neutral perception, and $0 \%$ teachers had negative perception. It shows that the teachers' code-switching has relation to classroom management.

This following table is the results of teachers' perception on the use of code-switching in relation to interpersonal relations. The results are presented in Table 4.

Table 4. Teachers' Perception towards Code-Switching in Relation to Interpersonal Relations

\begin{tabular}{lllllll} 
Aspect & \multicolumn{9}{c}{ Interpersonal Relations (\%) } & \multirow{2}{*}{ Average (\%) } \\
\cline { 1 - 1 } $\begin{array}{l}\text { Percentage } \\
\text { Response }\end{array}$ & S14 & S15 & S16 & S17 & S18 & (\% \\
\hline Strongly agree & 0 & 0 & 20 & 0 & 20 & 8 \\
\hline Agree & 80 & 60 & 60 & 80 & 80 & 72 \\
\hline Neutral & 20 & 20 & 20 & 20 & 0 & 16 \\
\hline Disagree & 0 & 20 & 0 & 0 & 0 & 4 \\
\hline Strongly Disagree & 0 & 0 & 0 & 0 & 0 & 0
\end{tabular}

This aspect aimed at investigating teachers' perception whether using code-switching could benefit the teachers to create good rapport between teacher and students. It was found that $8 \%$ teacher responded strongly agree, $72 \%$ teachers responded agree, $16 \%$ responded neutral, and $4 \%$ responded disagree. This means that $80 \%$ teachers had positive perception, $16 \%$ had neutral perception, and $4 \%$ had negative perception.

Teachers' Perception toward the Use of Code-Switching to EFL Young Learners

As shown in the questionnaire results, in the first aspect, there was a relatively fair number of teachers who think that they have good persona in switching codes from English to Bahasa Indonesia or from Bahasa Indonesia to English in a learning activity. In order to be able to do code-switching, the teachers should have good language proficiency both in Bahasa Indonesia and English. From the results of the questionnaire, T3 answered agree on the deficiency in English. This is interesting because the rest of the teachers answered that they are proficient in English. The following transcript illustrates the issue ( $\mathrm{R}$ stands for researcher and Tn stands for teachers)

$\mathrm{R} \quad$ : Why did you agree that the teachers who switch codes from English to Bahasa Indonesia are deficient in English? Do you think that you are deficient in English? 
T4 : Actually, when I teach my students at first grade and switch codes from English to Bahasa Indonesia, I cannot deliver the message well; therefore I think I'm still deficient in English.

The answer from teacher 4 shows that when the teacher switches codes from Bahasa Indonesia to English and the students cannot understand what is being delivered by the teacher, then the teacher considered himself as deficient in English. In fact, it can be caused by the level of the students being taught. Khaerunnisa (2016) implied that even though the teacher already uses students' first language or students' mother tongue in teaching foreign language, the students' at the beginner level cannot clearly accept what is being taught by the teacher.

Apart from that statement, all teachers stated that they could easily express themselves in both Bahasa Indonesia and English. When conducting interview, all teachers answered that they have no problem on this. The following transcript illustrates the issue.

R : : "When you do code-switching, do you think you can clearly express yourself in the languages?"

T1 : "It's not a big deal"

T2 : "Of course, I have to make sure it goes well in classroom."

T3 : "I can express myself clearly in both languages."

T4 : "Yes, I can."

T5 : "As an English teacher, it is a must."

Besides, the results presented on Table 2 indicate that the teachers had positive perception on how code-switching could assist subject access. They can also better explain the grammatical points and lexical items in the text and clarify the lesson content taught. The following transcript illustrates the issue.

$\mathrm{R} \quad$ : When you switch codes, is there any topic that you think it is difficult to switch codes?

T2 : So far, there is no any special topic that causes difficulty in code-switching. I can do it to all kinds of the topic, because it is important for young learner when the teachers do so.

Another transcript illustrates the issue.

$\mathrm{R} \quad$ : Do you think that switching codes can disturb a text's grammatical and lexical explanations?

T5 : No, it's not. I can explain them to the students but I have to focus the students as best as I could in order to make them understand.

The overall result of the interview related to the subject access shows that the teacher said that young learners' have a good memory that contributes to high levels of proficiency in two languages. It means that young learners may be able to remember the vocabulary in English quickly and they can easily achieve English proficiency like the native speaker if the teacher speaks English more often than Bahasa Indonesia in the classroom.

Related to the teachers' perception toward code-switching in relation to classroom management shows that the teachers' code-switching has relation to classroom management, an interesting result were found in the interview. There were four teachers that said that even though they had to use English frequently in English class, it was better for them to use Bahasa Indonesia to discipline the students. The following transcript illustrates the issue. 
R : When you switch codes from Bahasa Indonesia to English or from English to Bahasa Indonesia, can you manage the classroom well? For example like giving instruction or the other component of classroom management.

T3 : Sometimes, I use both Bahasa Indonesia and English to deliver the task instruction. However, I have my own way to discipline my students. I am their parents in this school, therefore I have to discipline them like the parents should do, and so it is better to tell their mistake or give reprimand in Bahasa Indonesia.

T1 : Using both languages in discipline the students? I think it is not necessary for young learners; it is enough to use Bahasa Indonesia only, so that they can understand clearly and they can maintain their positive behaviors.

From the teachers' answer, it can be seen that code-switching is not always work in relation to classroom management. The factor is the students are categorized as young learners, they just started to learn language, moreover English as a foreign language. Therefore, it will be better for them to use only Bahasa Indonesia in managing the classroom like giving instruction, focusing students' attention, and discipline the students. However, all teachers said that in giving reinforcement, they always code-switch the expression in English, like saying good job, well done, you are very smart, and so on.

The result of the questionnaire analysis regarding the interpersonal relations indicate that the teachers had positive perception towards it. When the teachers did code-switching, they could better create a good rapport between teacher and students like encouraging the students in learning activity. However, the teachers said that it is difficult for them to enliven the atmosphere of class using both Bahasa Indonesia and English, so it is impossible to make a joke by switching codes of both languages.

\section{Teachers' Strategy in Using Code-switching in EFL Young Learners Classroom}

After conducting interview to T1, T2, T3, T4, and T5, it was found that the teachers did code-switching by interchanging from English to Bahasa Indonesia or vice versa whenever they needed to provide information related to the meanings of English words to the students, whether it was related to the topic or the teaching instruction. The following transcript illustrates how the teachers used it.

$\mathrm{R} \quad$ : Can you give example how you switch codes in Bahasa Indonesia and English when teaching?

T1 : Siapa yang tahu artinya Lion? (Teaching about animal) (Who knows the meaning of Lion?)

T2 : Apakah Sunday kalian pergi ke sekolah? (Teaching about name of the day) (Do you go to school on Sunday?)

T3 : Wow, good job, you are very smart! Kamu sangat pintar, pekerjaanmu bagus sekali.

T4 : Show me your hands! Ayo, tunjukan yang mana disebut hands! (Teaching parts of body)

T5 : Apakah kalian mengerti? Do you understand, students?

The transcript indicates that T1 used Bahasa Indonesia dominantly. Code-switching to English was done only when new vocabulary was being introduced. Similarly, T2 also conducted 
the same strategy by only switching to English when new words were being introduced to the students. On the other hand, T3, T4, and T5 showed different strategy used in doing codswitching. The three teachers switched to Bahasa Indonesia when they had completed an expression in English, or vice versa. The switch was made by translating the expression that was previously stated in one of the languages.

Through this finding, it can be seen that the teachers did code-switching whenever they needed to introduce or say English vocabularies that were considered new or difficult for the students. Further, the results of the interview indicated that the teachers did code-switching with the aim of enriching the students' English vocabulary. It was because by doing so, the teachers believe that the students could get the meaning of the words easier and thus help them to use the target language.

\subsection{Discussion}

\section{English Teachers' Perception towards the Use of Code-Switching}

The findings indicated that the majority of the teachers had positive perception towards the use of code-switching in teaching English to the elementary school students. The perception was related to the teachers' persona, subject access, classroom management, and interpersonal relations. The results indicated that $50 \%$ of the teachers had positive perception in relation to teachers' persona, $70 \%$ had positive perception in relation to subject access, $84 \%$ had positive perception in relation to classroom management, and $80 \%$ had positive perception in relation to interpersonal relations.

The positive perception of code-switching use showed by the teachers in relation to their persona was in contrast to the findings suggested by Chen (2016). It was because the study by Chen (2016) indicated that teachers were rather uneasy in doing code-switching with the fear of being judged not proficient in English and made the students reluctant to use the target language. The result of this study was also in contrast with Yao (2011) who found that teachers often avoid using code-switching as they were worried that it would hinder students from speaking in the target language. Study by Bilgin (2016) also showed how teachers only preferred to use codeswitching occasionally to avoid being labeled as incompetent. This study indicates that the teachers believed that they still had good persona even though they often code switched their languages in teaching. Further, the results of the interview also indicated that the teachers felt comfortable in using code-switching, which was reflected by how they preferred to discipline their students in Bahasa Indonesia. This was similar to the results of the study conducted by Altun (2019) who also found that teachers felt at ease and comfortable when giving instruction and teaching in their mother tongue despite teaching foreign language.

A similar results, however, was found in the aspect of code-switching and subject access. As described on the findings, the teachers had positive perception towards the use of codeswitching in relation to subject access, with the percentage of $70 \%$. This positive result was similar to the study conducted by Stylianou (2015) and Khaerunnisa (2016). Stylianou (2015) found that code-switching was conducted by the teachers to put the students at ease in learning English, without necessarily directing them to be reluctant to the target language. Amalo (2018) suggests that teachers perceive code-switching positively as it is considered as one of timesaving techniques that can make the learning process efficient. A study by Luo (2019) even 
found that students also have positive perception towards code-switching as it helps them in comprehending the topics being learned. Similarly, Khaerunnisa (2016) also found that codeswitching was done so that better and clearer explanation regarding the topics being discussed could be delivered to the students. A greater percentage was even shown in the use of codeswitching in relation to classroom management with the total of $84 \%$. This could happen as the teachers felt more comfortable in teaching (Altun, 2019) and believed that the students would have better understanding of the target language just as suggested by Stylianou (2015) and Khaerunnisa (2016).

Similarly, the $80 \%$ positive perception on the use of code-switching in relation to interpersonal relations could also happen as the teachers perceived that the students had better understanding to the topics and the target language. Besides that, the fact that code-switching from Bahasa Indonesia to English and vice versa was done indicated that it is rather difficult for the teachers to only used English in teaching the students. This is supported by Danuatmadja (2016) who suggests that as students in Indonesia are learning English as a foreign language, it is difficult to use English all the time during teaching as students possess different level of comprehension. Thus, it becomes necessary for the teachers to conduct code-switching in order to avoid negative learning atmosphere. Similarly, Bhatti et al., (2018) and Suganda et al., (2018) also suggest that the use of code-switching is perceived as a way to build solidarity and intimate relationship, accelerate the warm-up session, maintain discipline, and get the attention of the students as it is used in the greetings, chatting, and during the learning process. Besides that, studies by Chughtai, Khan, and Khan (2016) and Lee (2019) also suggest that young learners are reported to have better acquisition of new vocabularies through the use of code-switching.

\section{Teachers' Strategy in Using Code-switching in EFL Young Learners Classroom}

The results of the interview regarding the strategy used by the teachers in using codeswitching to teach English to EFL young learners indicated that they use the same strategy. The results showed that code-switching was used when the teachers needed to introduce students with certain vocabularies or expressions that were considered new or difficult for the students. Further, the code-switching was done either by inserting targeted English words in an utterance spoken in Bahasa Indonesia or by speaking in one of the languages first and then translated it to the other language.

The strategy used by the teachers reflects the core concept of what code-switching itself. It is as suggested by Nurhamidah et al., (2018) and Gustavsson and Karakitsos (2019) that codeswitching involves the switch of words within the same context between two or more languages codes. The strategy used by the teachers, when being seen from the results of other studies, was understandable. It is because as suggested by Danuatmadja (2016), Indonesian students are learning English as a foreign language, it is difficult to use English all the time during teaching as students possess different level of comprehension. Further, as the teachers also perceived code-switching positively, the strategy used in doing code-switching was even become more normalized. As studies by Stylianou (2015), Khaerunnisa (2016), Ansar (2017), Chughtai et al., (2016), and Song and Lee (2019) show that doing code-switching from one language to the other can help the students to feel at ease and understand the materials, the strategy used by the teachers would be a great method in the EFL teaching and learning context. 


\section{CONCLUSIONS}

\subsection{Conclusion}

By doing code-switching, the teacher aimed at enriching students' vocabulary in English because when they know the meaning of the words, it will be easier for them to use the language. This study focused on investigating the teachers' perception towards the effectiveness of using code-switching to the EFL young learner in SD Lab Undiksha Singaraja, Bali and the strategy used in using code-switching to teach the EFL young learner.

The results of this study indicated that code-switching is something inseparable from the EFL teaching and learning context in Indonesia. This study focused on investigating teachers' perception toward the use of code-switching to EFL young learners in SD Lab Undiksha, Singaraja. The findings of the perception show that the teachers' code-switching has relation to teachers' persona, subject access, classroom management, and interpersonal relations. It shows that the teachers had positive perception towards the use of code-switching.

English class, managing the classroom like giving task instruction, and create a good rapport between teachers and students. The strategy that the teachers often used in the process of code-switching was by explaining the similar or the meaning of the words and the phrases to present the exact vocabularies students needed to know. Code-switching is a good alternative for the teachers to teach English for EFL young learners, however, sometimes the teachers have to think about the other strategy that can be used in switch codes, therefore the students can still maximize their potential in using the target language.

\subsection{Suggestions}

As this study was conducted on the teachers who teach students in elementary school level, further researches are expected to be conducted in higher education level. It is important to be conducted in order to provide data related to how teachers perceive code-switching in higher education as well as to find out the strategies used in conducting code-switching to older learners. As older learners typically have more knowledge of the English vocabulary, it becomes interesting to know whether code-switching is used and needed as well as how the teachers use and perceive it.

\section{REFERENCES}

Altun, S. (2019). The Interaction of Code-switching and EFL Teachers' Perceptions on their Teacher Identity Development. Advances in Language and Literary Studies, 10(1). https://doi.org/http://dx.doi.org/10.7575/aiac.alls.v.10n.1p.163.

Ansar, F. A. (2017). Code Switching and Code Mixing in Teaching-Learning Process. English Education: Jurnal Tadris Bahasa Inggris IAIN Raden Intan, 10(1), 29-45.

Bhatti, A., Shamsudin, S., \& Said, S. B. M. (2018). Code-Switching: A Useful Foreign Language Teaching Tool in EFL Classrooms. English Language Teaching, 11(6), 93. https://doi.org/10.5539/elt.v11n6p93. 
Bhatti, N., \& Pathan, H. (2016). Investigating the Perceptions of Pakistani English Language Learners on Language Learning Anxiety in EFL Classroom. Advances in Language and Literary Studies, 7(5). https://doi.org/10.7575/aiac.alls.v.7n.5p.23.

Bilgin, S. (2016). Code Switching in English Language Teaching (ELT) Teaching Practice in Turkey: Student Teacher Practices, Beliefs and Identity. Educational Research and Reviews, 11(8), 686-702. https://doi.org/10.5897/ERR2016.2802.

Cantone, K. F. (2007). Code-switching in Bilingual Children Studies in Theoretical Psycholinguistics. The Netherland: Springer.

Chen, J. (2016). An Investigation into Teacher Code-switching in EFL Classrooms at Tertiary Level in China. ICLLS, 148-164.

Chughtai, I. A., Khan, M. A., \& Khan, M. R. (2016). Reasons and Contexts to Switch and Mix English by Pakistani Young Learners in Their Native Speech: A Sociolinguistic Study. International Journal of Language and Linguistics, 3(1), 85-94.

Creswell, J. W., \& Clark, V. L. P. (2007). Designing and Conducting Mixed Methods Research. CA: Sage.

Danuatmadja, N. A. (2016). Kindergarten Teachers' Views toward the Code Switching Strategy.

Gustavsson, B., \& Karakitsos, A. (2019). Degree Project with Specialisation in English Studies in Education Teacher and Teacher Student Beliefs on Using Code-Switching in EFL Classrooms. Malmo University Press.

Istiqomah, F. (2016). Reintroducing The Important of Teaching English at Primary Schools in Indonesia. Lingua Scientia, 8(1).

Khaerunnisa, L. (2016). An EFL Teacher's Code Switching in a Young Learners' Class. Indonesian Journal of EFL and Linguistics, 1(1), 13-31. https://doi.org/10.21462/ijefll.v1i1.1.

Kurniati Amalo, B. (2018). Teachers' Beliefs and Perceptions of Code Switching in English as Foreign Language Classroom. SHS Web of Conferences, 42, 00034. https://doi.org/10.1051/shsconf/20184200034.

Lauder, A. (2008). The Status and Function of English in Indonesia: a Review of Key Factors. Makara Human Behavior Studies in Asia, 12(1), 9. https://doi.org/10.7454/mssh.v12i1.128.

Luo, Y. (2019). Chinese University Students' Perceptions of teacher Code-switching in EFL Speaking Classrooms. English Language Teaching, 12(11), 119. https://doi.org/10.5539/elt.v12n11p119.

Marlina, L. (2013). Learning English as Foreign Language in Indonesia through English Children's Literature. The International Journal of Literacies, 19(4). 
Nurhamidah, Fauziati, E., \& Supriyadi, S. (2018). Code-Switching in EFL Classroom : Is It Good or Bad? Journal of Enionglish Education, 3. http://dx.doi.org/10.31327/jee.v3i2.861.

Ratminingsih, N. M. (2017). Metode dan Strategi Pembelajaran Bahasa Inggris. Depok: PT Raja Grafindo Persada.

Song, D., \& Lee, J. H. (2019). The Use of Teacher Code-Switching for Very Young EFL Learners. ELT Journal, 73(2), 144-153. https://doi.org/10.1093/elt/ccy049.

Stylianou-Panayi, N. (2015). Code Switching in an EFL Environment. Linguistics and Literature Studies, 3(6), 259-263. https://doi.org/10.13189/1ls.2015.030601.

Suganda, L. A., Loeneto, B. A., \& Zuraida, Z. (2018). Teachers' Use of Code Switching in An English as a Foreign Language Context in Indonesia. Script Journal: Journal of Linguistic and English Teaching, 3(2), 111. https://doi.org/10.24903/sj.v3i2.202.

Ummah, M. (2017). Review of Students perception and Students ' Learning Preferences in Learning English at SDN 1 Sembayat. English Teaching, Literature, Applied Linguistics, 1(2), 16-21.

Yao, M. (2011). On Attitudes to Teachers ' Code-switching in EFL Classes. World Journal of English Language, 1. https://doi.org/10.5430/wjel.v1n1p19.

Yildırım, R. (2015). EFL Teachers' Code Switching in Turkish Secondary EFL Young Language Learner Classrooms. International Journal of Linguistics, 7. http://dx.doi.org/10.5296/ijl.v7i1.6750\%0AAbstract. 